\title{
A framework for the digitisation of records and archives at selected state universities in Zimbabwe
}

\begin{tabular}{|c|c|}
\hline \multicolumn{2}{|c|}{$\begin{array}{l}\text { Authors: } \\
\text { Godfrey Tsvuura }{ }^{1} \\
\text { Patrick Ngulube }\end{array}$} \\
\hline \multicolumn{2}{|c|}{$\begin{array}{l}\text { Affiliations: } \\
{ }^{1} \text { Department of Information } \\
\text { Science and Records } \\
\text { Management, Faculty of } \\
\text { Applied Social Sciences, } \\
\text { Zimbabwe Open University, } \\
\text { Harare, Zimbabwe }\end{array}$} \\
\hline \multicolumn{2}{|c|}{$\begin{array}{l}{ }^{2} \text { School of Interdisciplinary } \\
\text { Research and Graduate } \\
\text { Studies, College of Graduate } \\
\text { Studies, University of South } \\
\text { Africa, Pretoria, South Africa }\end{array}$} \\
\hline \multicolumn{2}{|c|}{$\begin{array}{l}\text { Corresponding author: } \\
\text { Patrick Ngulube, } \\
\text { ngulup@unisa.ac.za }\end{array}$} \\
\hline \multicolumn{2}{|c|}{$\begin{array}{l}\text { Dates: } \\
\text { Received: } 17 \text { Sept. } 2020 \\
\text { Accepted: } 28 \text { May } 2021 \\
\text { Published: } 19 \text { July } 2021\end{array}$} \\
\hline \multicolumn{2}{|c|}{$\begin{array}{l}\text { How to cite this article: } \\
\text { Tsvuura, G. \& Ngulube, P., } \\
2021 \text {, 'A framework for the } \\
\text { digitisation of records and } \\
\text { archives at selected state } \\
\text { universities in Zimbabwe', } \\
\text { South African Journal of } \\
\text { Information Management } \\
\text { 23(1), a1312. https://doi. } \\
\text { org/10.4102/sajim. } \\
\text { v23i1.1312 }\end{array}$} \\
\hline \multicolumn{2}{|c|}{$\begin{array}{l}\text { Copyright: } \\
\text { C 2021. The Authors. } \\
\text { Licensee: AOSIS. This work } \\
\text { is licensed under the } \\
\text { Creative Commons } \\
\text { Attribution License. }\end{array}$} \\
\hline \multicolumn{2}{|l|}{ Read online: } \\
\hline 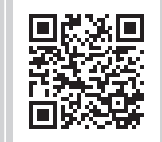 & $\begin{array}{l}\text { Scan this QR } \\
\text { code with your } \\
\text { smart phone or } \\
\text { mobile device } \\
\text { to read online. }\end{array}$ \\
\hline
\end{tabular}

Background: This study examines the digitisation of records and archives at two state universities in Zimbabwe that have embarked on digitisation of their records and archives resources in line with new technological trends of doing business online.

Objectives: One of the objectives of this research study was to identify the gaps existing in the digitisation of records and archives at the two selected state universities and recommend ways of filling those gaps. The other objective was to find out if the state universities have adopted a framework or model for the smooth digitisation process of the records and archives.

Methods: The study adopted a qualitative multiple-case research design to provide an indepth understanding of the cases of the digitisation of records and archives at the selected state universities. Data were collected via purposive sampling using interviews.

Results: The major findings of this study revealed that the two state universities are digitising records and archives without a framework or model for a smooth digitisation programme.

Conclusion: The study recommends for a centralised model to cater for the digitisation of records and archives at the state universities in Zimbabwe. A model for managing digital records and archives which combines best practices and top management support with a centralised approach is proposed. This model is built on integrated systems that will enable the two selected state universities to enhance cost-effectiveness, sharing and exchanging digital records and archives amongst employees. This study is pertinent as it enriches the literature in the field of records and archives management and provides strategies on the management of digital records and archives in state universities in Zimbabwe.

Keywords: digitisation; records and archives; integrated systems; centralised framework; university records

\section{Introduction}

This research study investigates the digitisation of records and archives at two selected state universities in Zimbabwe, namely, Zimbabwe Open University (ZOU) and Harare Institute of Technology (HIT). The two state universities have embarked on digitisation of their records and archives resources in line with new technological trends of carrying out business online in both teaching and administration. Mukred et al. (2019), and Mukred and Yusof (2018) stated that digital technology in the educational sector can play a positive role in building on traditional learning and teaching methods, enabling students to have easy access to the information they need and leveraging academic achievements. However, Ambira, Kemoni and Ngulube (2019) observed that digitisation, in most cases, is disjointed and uncoordinated, with each section adopting its strategy and approach. Such practices negate the collective principle and responsibility of working jointly towards delivering goods and services to stakeholders (Ambira et al. 2019).

The objective of this study was to determine whether the state universities were using a model or framework for managing the digital records and archives, as digitisation of records and archives must be a well-planned project with adequate resources and framework of operation (Tsvuura \& Ngulube 2020). Another objective was to identify the gaps that exist in the digitisation of records and archives in the two selected state universities and recommend ways of filling those gaps, if they exist.

\section{Background and context of the study}

The change in recordkeeping from paper-based to digital records has challenged the existing procedures of recordkeeping. Thibodeau (2013) revealed that the transition from paper records to 
digital records management has been embraced and adopted globally with its fragmented arrays of successes, failures and challenges. This transition from paper to digital records and archives has created gaps in the quality of service delivery (Ambira et al. 2019). According to the authors, the ability to coordinate and share information is hampered in cases where policies for information sharing and management of digital records do not exist. The lack of a clear framework for managing digital records poses a major risk to the sustainability, stability and quality of services offered through electronic platforms (Ambira et al. 2019). Despite the good initiatives of adopting digital records and archives management, Ambira et al. (2019) recommended for a framework to guide the management of digital records.

The literature has shown that the use of digitised records and archives has widely been accepted in organisations throughout the world, as it has brought in a new dispensation with a great deal of changes in modernising business processes, communication, financial management and decision-making (Asogwa 2013; Asproth 2005; Chinyemba \& Ngulube 2005). The literature has also revealed that a portion of society's recorded memory created and preserved digitally has already been compromised and become inaccessible (Duranti 2009; Duranti \& Jansen 2016). The digitisation of records and archives has been widely accepted and become an essential part of government structures in both the developed and developing countries. The adoption of digitised records and archives management in the two selected state universities has led to the decentralisation of information through networks, servers, memory sticks, databases, as well as websites in large volumes (Tsvuura 2020). This has resulted in organisational records being stored in individual employees' laptops and memory sticks, who leave the organisations carrying the records with them (Tsvuura \& Ngulube 2020). A lack of university records management policies that separate official business records from personal records result in the loss of ownership and organisational records embedded in individual laptops and private email inboxes, having a great risk of being lost. The main organisational e-mail records that are transmitted during business hours are easily personalised and kept as private records in individual inboxes of Google mail accounts, and carried away by personnel whilst leaving the organisation. This implies that adequate and clear policy frameworks on what to do with digitised records and archives are required, including where they should be kept and who should be responsible for their safe custody. It is in this respect that every organisation whether big or small should ensure that its records are able to stand for the facts for which they are created.

This study focused on the digitisation of records and archives at two selected state universities in Zimbabwe, namely, ZOU and HIT. The objective of this study was to evaluate the legal and statutory frameworks for managing the digitisation of records and archives at the state universities. The legislative and statutory imperatives in Zimbabwe, the exponential growth in digitised records and archiving in the state universities, and the lack of trained records personnel for the management of digital records and archives motivated this study. The two state universities have embraced digitisation and they are creating digital records of two formats, that is, by conversion of paper records through scanning into electronic or digital and by creating (born digital) records on the computers. Digitised records and archives are documents created and maintained using the digital computer technology (Tsvuura \& Ngulube 2020:23). The digitisation process has enabled the state universities to provide an improved access to information sources, and the preservation and dissemination of information as required, where it is required and the time it is required. This study is premised on the fact that digital records and archives require appropriate management, legislation, policies, procedures and guidelines. They also require the services of trained records personnel, who would be at the heart of the state universities' drive towards delivery of digital services. By undertaking this study, the researchers wished to underscore why it is necessary for the state universities to understand the concepts of recordkeeping, contextualise it, and be able to use digital records and archives for business objectives and strategies.

Whilst Cumming and Findlay (2010) asserted that the prophesied paperless office will never exist, the fluidity, flexibility and diversity of digital business environment have also brought in proliferation of digital records and archives. The same authors highlighted that the sheer volumes involved in terms of numbers of record formats require active and ongoing integrative management. This has also demanded from governments legislation and policies on digital records and archives, including the use of electronic signatures (e-signatures), to formalise the acceptance of such records as official records and legalise their admissibility as evidence in courts of law. McDonald (2002) noted that the majority of developing countries still lag in digital recordkeeping and cited a lack of efficient digital records management skills and scarcity of records management professionals. Lipchak and McDonald (2003) argued that legislative and regulatory frameworks are important parts of the environment for managing digital records. This has also been supported by Munetsi (2011) who alluded that legal and regulatory measures are components required to foster recordkeeping in the face of challenges of managing digital records and archives. The above statement by McDonald (2002) is the situation on the ground in Zimbabwe, as the country is grappling to come up with legislation that governs digitised records and archives. In this regard, digitised records and archives, just like their paper counterparts, should support evidence-based decisions in a court of law and comply with the national laws of Zimbabwe and international standards. However, Duranti and Jansen (2016) noted that digitisation itself is challenging the viability and legitimacy of many well-established social and cultural norms and their associated legal frameworks. In this regard, universities in Zimbabwe have not been spared. 
It has become a norm all over the world that organisations should have sound records management frameworks that would assist them to access records for appropriate decisionmaking. According to Asogwa (2013:793), tertiary institutions can only be effective and efficient if records management is considered a business process designed to support institutional objectives. In this regard, as tertiary institutions move into digitisation, they need to make sure that the technological tools they are investing in are supported by legal, policy and business structures that would make the digitisation process effective. Hofman, Duranti and How (2017:2) argued that in order to meet minimum expectations and ensure that recorded memory is well preserved, technological tools must be supported by legal, social and business structures. This also requires the hiring of professional records personnel who must develop appropriate strategies, procedures and standards that will meet best practices.

In other words, the recommended centralised records management model is based on these records management principles, which may assist tertiary institutions to develop sound digital records management systems, include records management policy, staff with records management responsibilities, management oversight, strategic planning and resource allocation, operational procedures, practices and systems, communications, and monitoring and reporting mechanisms (Victorian Auditor-General's Office 2016).

\section{Benefits of managing digitised records and archives}

Tsvuura and Ngulube (2020:21) stated that digitised records and archives are documents created and maintained by digital technology. Technology itself has created the possibilities to improve the quality of service delivery in most, if not all, organisations around the world. Today, the ability of any organisation to perform well hinges on its adoption of technology and how that organisation infuses into sustainability of that technology. As observed by Asogwa (2013:792), efficient records and archives management provide reliable information that may be inevitably needed for effective functioning of organisations. 'Reliable records and archives enables organisations to perform their functions successfully and efficiently' (Asogwa 2013:792). Accordingly, records and archives despite the media they are captured on are the campus or atlas of any organisational journey on which it relies on. Managing digital records and archives ensures that organisations have appropriate tools for access to the required records in a consistent and accountable manner. One of the major advantages of having digitised records and archives is the fact that these materials can be accessed through computer technology and even remotely. According to Balogun and Adjei (2019:614), millions of users can have access to the files online via the internet regardless of their locations, and copies can be made several times without degradation of the contents.

\section{Challenges of managing digital records and archives}

The challenges of managing digitised records and archives have been surmounting from the introduction of electronic recordkeeping systems. Despite the tremendous capabilities of digital recordkeeping systems, Asogwa (2012:205) noted that technology continue to evolve, and hence, transferring records from old to new digital systems require substantial reformatting and restructuring of the records. Accordingly, Thibodeau (2013) argued that the relationship between what is stored and what is presented to a human being can be both complex and variable, as what would be presented to human beings as a single object may comprise of content drawn from many different data stores.

Thibodeau (2013) elaborated that one of the challenges of managing digital records is that every time when digitised records are copied to a different storage medium and whenever they are transmitted on a network, they change their format in one way or another. Earlier on, Duranti (2010:78) propounded that 'the greatest challenge with digital systems is the creation and maintenance of reliable records and the preservation of their authenticity over time'. According to Mutsagondo (2021:94), amongst the challenges to effective management of digital records are the lapses in legal policy and procedural frameworks, skills and information and communication technology infrastructure deficiencies. Coupled with all these challenges is the difficulty of preserving digital records for future use in order to sustain business operations (Ngulube 2012).

\section{Statement of the problem}

With the advent of technology, digitisation of records and archives transformed the way business is being performed in state universities, and consequently, the nature of how they are managed. This implies that a clear framework for managing digital records is necessary in order to reduce the risk to the sustainability, stability and quality of services offered through electronic platforms (Ambira et al. 2019). A top management strategy is also important to ensure that erroneous information dissemination and preservation do not occur. The extent of management support for the management of digital records and archives, and the effectiveness of the framework for managing digital records are not adequately known. The main objective of this study was to identify the gaps that exist in the digitisation of records and archives at the two selected state universities and recommend ways of filling those gaps, with a focus on top management support and the management of digital records framework. The questions to guide the study were formulated as follows:

1. What is the current state of the digitisation process at the two state universities?

2. What framework is used for managing digital records and archives at state universities in Zimbabwe?

3. What infrastructure is employed for the smooth digitisation process at state universities in Zimbabwe? 
4. How is the top management involved in the digitisation of records and archives processes?

5. What strategies can be employed to strengthen the digitisation of records and archives?

\section{Literature review}

Alkhofani et al. (2019:1) outlined that prior to the digitisation process of records and archives, there are factors that need to be known, which include organisational and technological factors. The other factor is top management commitment and support to the digitisation process, as it guarantees funding and employees' awareness (Alzubi, Aldhmour \& Ali 2015:180). Mutsagondo and Ngulube (2018) noted that lack of senior management support and inadequate resources result in unsuccessful digital records and archives management programmes, as junior records staff could not influence organisational policies towards their discipline. Top management allocates budget that plays a key role in meeting the financial demands of digitisation (Alkhofani et al. 2019:5). A lack of budget could prevent successful implementation of digitisation of records and archives programmes (Cucciniello 2015:268). Hasanain, Vallmuur and Clark (2015) argued that communication between top management and subordinates in the digitisation process is essential, as it facilitates sharing of ideas, information and data amongst stakeholders. According to Nguyen, Bellucci and Nguyen (2014:780), communication is deemed to be a change management tool in resolving issues and in ensuring timely sharing of information across the departments in the right format. In addition, Fuin-Hoon Nar, Lee-Shag Lau and Kuang(2001:288) opined that communication raises high-level staff willingness and top management commitment in the initiative and facilitates successful implementation of the digitisation process.

Both Abdulkadhim et al. (2015) and Shatat (2015) identified experienced and skilled personnel and user involvement as a critical factor to the successful implementation of the digitisation process. Mutsagondo and Ngulube (2018) noted some anomalies and poor digital records management skills amongst personnel who manage digitised records and archives. Chaterera (2012), Nasieku (2012), Mutsagondo (2017) and Mutsagondo and Ngulube (2018) argued that many records officers lack information and communication technology (ICT) skills because they were not inculcated in them during formal training. Mutsagondo and Tsvuura (2017) bemoan that a number of officers managing records were not trained in records management or were professionals from other backgrounds, such as secretarial and administration. Mutsagondo and Ngulube (2018) argued that this has become a thorny issue in records management discourses in many developing countries, as many countries in sub-Saharan Africa experience skills gaps amongst records professionals. Tsvuura and Mutsagondo (2015) hold that some officers who manage digital records are not qualified. This was supported by Sigauke, Nengomasha and Chabikwa (2016) when they noted that there was a lack of qualified records management staff from amongst officials who were responsible for managing digital records in state universities in Zimbabwe. However, Alkhofani et al. (2019:5) outlined that training is essential, and argued that training allows users effective and efficient operation of a new system. Training services plays a major role in the success of the new system (Asogwa 2012).

In their study on admissibility of digital records as evidence at the Bulawayo High Court in Zimbabwe, Huni and Dewah (2019) hold that without policies in place, there is no consistency, compliance, good practice or uniformity in the administration of business transactions. Policies and procedures act as a guide to facilitate activities in the digitisation process in a clear and extensive manner (AsimaMakhtar \& Yusof 2009). Digital records and archives are susceptible to manipulation, alterations and deletion, and if there are no valid policies that are understood by staff members responsible for their management, the whole operations will be performed in a hit-or-miss approach (Huni \& Dewah 2019; Mutsagondo \& Tsvuura 2017). Mutsagondo and Tsvuura (2017) added that if there are no policies, records practitioners will be placed between a rock and hard surface, as well as placed on the horns of a dilemma as they juggle between options as to how they should professionally manage such records. They listed three causes of the dilemma to managing digital records and archives: firstly, the regulatory and legal framework governing digital records and archives management in Zimbabwe is in shambles. Secondly, digital records and archives management is seriously dented by lack of skills in information and communication technologies and digital records and archives management. Thirdly, digital records and archives management had been introduced before the laws and frameworks were put in place, resulting in individuals resorting to own ways of managing such records. Dube (2011), Mutsagondo and Chaterera (2016) and Huni and Dewah (2019) expressed that lack of legislation has a negative impact on the management of digital records and archives. Dube (2011) categorically stated that obsolete and out-oftouch with technological developments legislation could not help to solve the problems experienced in the digital environment. Tsvuura, Mbawuya and Ngulube (2021:120) observed that many organisations are struggling to formulate new policies and laws to address electronic records management. The situation has not changed as Nasieku (2012) and Kamatula (2010) noted that policies and guidelines to manage digital records were non-existent, weak or outdated in many developing countries.

Abdulkadhim et al. (2015:17948) brings in information technology (IT) infrastructure as core to the digitisation of records and archives as it incentivises good performance of tasks, jobs and responsibilities. As digitisation is based on the IT infrastructure, ineffective IT infrastructure can affect the end product (Alkhofani et al. 2019:6). A good technological infrastructure and its technical support are a must for the smooth digitisation process, and lack of it can lead to adoption challenges and ultimately failure (Alkhofani et al. 2019:6). 


\section{Theoretical framework}

This study adopts a comprehensive technology-to-performance theoretical framework suitable for the proposed centralised model for strengthening the digitisation of records and archives at state universities. The theoretical framework was propounded by Goodhue and Thompson (1995) as they found a moderate empirical support for direct links between task and technology for successful performance in organisations. Orlikowski (2000) highlighted that the relationship between technology, organisational processes and performance is of great importance to the completion of tasks assigned. Digitisation is one of such technologies adopted by universities into their processes with the hope of enhancing performance. Information technology now exists to enable employees to engage in global activities critical to their organisations (Malhotra \& Majchrazk 2005). The technology-to-performance theory resonate well with the proposed centralised model for the digitisation of records and archives at state universities. The proposed centralised model has requirements, key strategies for implementation and desired results. In this instant, the interventions by the two selected state universities should ensure that the technological infrastructure for digitisation is made available, and followed by enforcement and implementation of rules and regulations in the creation of digitised records and archives. The end product, which is the digitised record, will be desirable and useable. In a nutshell, the technology-performance requirements for smooth digitisation includes effective IT infrastructure, strategic alignment, and organisational structure, which result in innovation of digitisation programmes.

\section{Method}

The researchers adopted a qualitative multiple-case design to enquire into the experiences of the participants who are involved in the digitisation of records and archives. With roots in social and cultural anthropology, philosophy, history and sociology, qualitative research is a form of social action that stresses on the way people interpret and make sense of their experiences to understand the social reality of individuals (Haradhan 2018:2). A multiple-case study approach was adopted to provide an in-depth understanding of a case or cases of the digitisation of records and archives at the selected state universities. Yin (2014) argued that a multiple-case study design allows replication logic as each participant is viewed as a single-case study in their own right. This study design is also highly effective in achieving a deep understanding of the specific phenomenon (Creswell 2014). The population of the study included the two registrars of the state universities who were purposively chosen and interviewed to get an in-depth understanding of the phenomenon at hand. Data are collected from interviews by recording answers. The researchers then gave a unique identifier to the recorded data as a first step of analysis. They identified segments of meanings from the data provided and labelled them as participant 1 and participant 2 . The two participants were adequate enough to facilitate theoretical saturation (Strauss \& Corbin 1990) or information redundancy (Lincoln \& Guba 1985). Coding and categorising data helped researchers to create inventories of data and acquire deep, comprehensive and thorough insights into the data (Miles, Huberman \& Saldana 2013; Saldana 2015).

\section{Data findings and analysis}

The participants from the two selected state universities were asked about the current state of the digitisation of records and archives at their universities. They answered that digitisation of records and archives that were ongoing at their universities as they were conducting organisational business using computers and online platforms. They were further asked if they had adequate infrastructure for the digitisation processes. Participant 1, a male professional who was Registrar at one of the universities said that:

'... The infrastructure for the digitisation of records and archives need improvement as the current state was demanding in terms of latest technology and adequate scanners to convert paper records into electronic formats.'

Participant 2 had this to say, '... as a technologically driven state university, there is adequate infrastructure for all processes undertaken by staff at the university'. Both participants were further asked about the strategies they employed to strengthen the digitisation processes. Participant 1, a male professional who was Registrar at one of the universities said that:

\begin{abstract}
'... The university has a digital records management policy and an email records management policy that was introduced in 2016. These policies provide guidelines on how we should conduct our business using computer technology. In the process we are creating digitised records and archives. However, there is great need for effective enforcement and implementation of these policies through procedures. There is need cooperation between the records management units and the ICT department, so that proper digital recordkeeping within the university is practiced. The ICT department of the university needs to play a pivotal role on the issues of digitisation of records and archives as this requires cooperation of expertise between records personnel and the ICT department.'
\end{abstract}

\section{Participant 2 provided three pertinent issues:}

'... there is need to develop a records management framework document (policy) to guide on digitisation of records and archives and their continuous migration as technology changes; successful completion of the student records/data management system will go a long way in effective management of students records, and the records management section has to continuously receive financial support from the university management to enable its proper functioning in recordkeeping matters.'

The participants were asked whether they had a framework on which they were able to control and strengthen digital records management within their universities. Participant 1, a male professional who was Registrar at one of the universities said that:

'... The university established a Records Committee of Senate which at intervals meet and deliberate on issues of records management in the university. The records committee of senate is composed of members from various units within the university and it reports to Senate which is the highest decision-making 
board of the university. This indicates that there is adequate support of records management activities within the university. However, there is need for enforcement of records policies to have an effective digitisation programme.'

Participant 2 suggested the following three critical aspects: training of records management personnel and all staff members within the institutions on proper recordkeeping as records help in decision-making, implementation of the records management policy documents and establishment of records management committee at an institutional level.

\section{Discussion}

The study findings established that there was a policy framework for the management of digitised records and archives at ZOU, whilst there was no policy framework at HIT. However, the study revealed that even ZOU has a policy framework for the management of digitised records and archives, and this policy framework was not being effectively followed as the participant indicated the need to fully implement the policy. In light of these findings, the study recommended a centralised model for strengthening the digitisation of records and archives at the selected state universities. Sigauke, Nengomasha and Chabikwa (2016:24) supported the adoption of an integrated and collaborative framework for managing emails as digitised records at state universities in Zimbabwe. Nguyen et al. (2009) also proposed a centralised electronic records management system in the Australian public sector for effective implementation of the electronic records management system. Ouma (2012:32) holds that integrated solutions and opportunities to work with partners can improve services at state universities. In their study, Abdulkadhim et al. (2015:17945) established an adoption model that demonstrates a strong correlation between digitisation efficiency, decision-making, technology acceptance and team adaptiveness.

The rapid changes in university business and adoption of technology result in the digitisation of records and archives in order to achieve competitive advantage. In this instance, top management is important for the successful digitisation process because they bring a clear change in management plan and strategy. Katuu (2000:34) argued that digitisation is often seen as the more glamorous because of its various benefits, such as reduced time of retrieval, multiple access points and enhancement. Such technology lowers constraints, such as resistance to change, and expand opportunities, such as potential benefits and advantages of digitisation (Floridi 2014:205). Many universities globally have adopted digitisation of records and archives, and they have recognised that it has made a positive impact on their performance (Alzubi et al. 2015:1). According to Alzubi et al. (2015:2), this has enabled them to link their internal and external data processing systems more efficiently and flexibly to work more closely with their students and staff and to better satisfy the needs and expectation of their clients. Digitisation of records and archives helps to simplify routine procedures and to make data and information more easily accessible to all beneficiaries regardless of the time and place (Smit, Glaudemans \& Jonker 2017:308). Another benefit and important contribution of digitisation on the universities have been in reducing the transaction times and costs (Alzubi et al. 2015:1). Smit et al. (2017:307) hold that many organisations continue to invest large amounts of resources in ICT, and therefore, to determine the potential acceptance of these new technologies is important. Alzubi et al. (2015:2) hold that if these new ICTs are accepted and adopted by users, the chances of the systems and investments' success greatly increase.

The study also established that digitisation of records and archives at the state universities is beset with some hurdles. These findings further underscore the need for the state universities to adopt digitisation as this could help them to invest in technology. In addition, digitisation of records and archives comes with costs of investments in hardware and software infrastructure, including training of personnel. This is in view that the participant 1 outlined that the infrastructure for the digitisation of records and archives needs improvement as the current state was demanding in terms of the latest technology and adequate scanners to convert paper records into electronic formats. Katuu (2000:34) observed that digitisation at the national archives of countries, such as United States, Canada and United Kingdom, has been known to cost millions of dollars. However, today, the flexibility of the new technologies allows organisations to use cloud-based applications provided by service providers through various networks (Tsvuura, Ngulube \& Mbawuya 2021). The cost includes that of technology, which include both hardware, software and constant challenges maintaining and upgrading in order to avoid obsoleteness (Katuu 2000:34). Another cost is that of manpower training and continuous education. The state universities have to consider the issue of technology dependence, where digitised records are created using particular hardware and software. It is crucial not to forget that digital resides somewhere and usable according to a particular technology and subject to an enormous amount of risks, like a virus or wrong click of the mouse (Smit et al. 2017:308). Alzubi et al. (2015:2) argue that digitisation require a modern and flexible organisational structure. Several studies have shown that top management support is a significant predictor of technology adoption (Alzubi et al. 2015:2).

In light of the findings, the study recommends a centralised model, as illustrated in Figure 1, to strengthen the digitisation of records and archives within the state universities. Sigauke et al. (2016:24) argued that a proposed framework is based on three tiers of policy: technological infrastructure, professional training and capacity development. This would enable personnel responsible for the management of digitised records and archives to be guided accordingly when undertaking digitisation processes. Mutsagondo and Tsvuura (2017) concluded that the management of digitised 
records need to be seriously addressed in order to cover all aspects, such as creation, receipt, use, maintenance, transfer and destruction. The last two aspects of transfer and destruction are very crucial as they dictate the availability of records now and in the future (Huni \& Dewah 2019). Ngulube (2012) issued a warning that a relaxed approach to digital records and archives management may sooner rather than later plunge the world into digital amnesia and the digital dark age. This study recommended a model for managing digital records and archives, which combines policies, best practices and top management support for effective digitisation programme in a centralised approach. In agreement with this, InterPARES Trust (2014) explored issues concerning digital records and data entrusted to the Internet, with a goal of generating theoretical and methodological frameworks to develop a variety of instruments that ensure public trust grounded on the evidence of good governance, strong digital economy and persistent digital memory.

It was within this context that this study synthesised the findings and available literature on digitisation of records and archives, electronic records management, best practices, international standards, regulatory and compliance to create a digital recordkeeping framework, and came up with a centralised model for recordkeeping, which could be adopted for managing digital records and archives in state universities. This model is built on integrated systems that will enable the two selected state universities to enhance cost-effectiveness, sharing and exchanging digital records and archives amongst employees. These include infrastructural, implementation and administrative requirements that will bring the desired results. The centralised model has been simplified in Figure 1. Centralising records and archives storage help to focus on control of digital records management, thereby improving

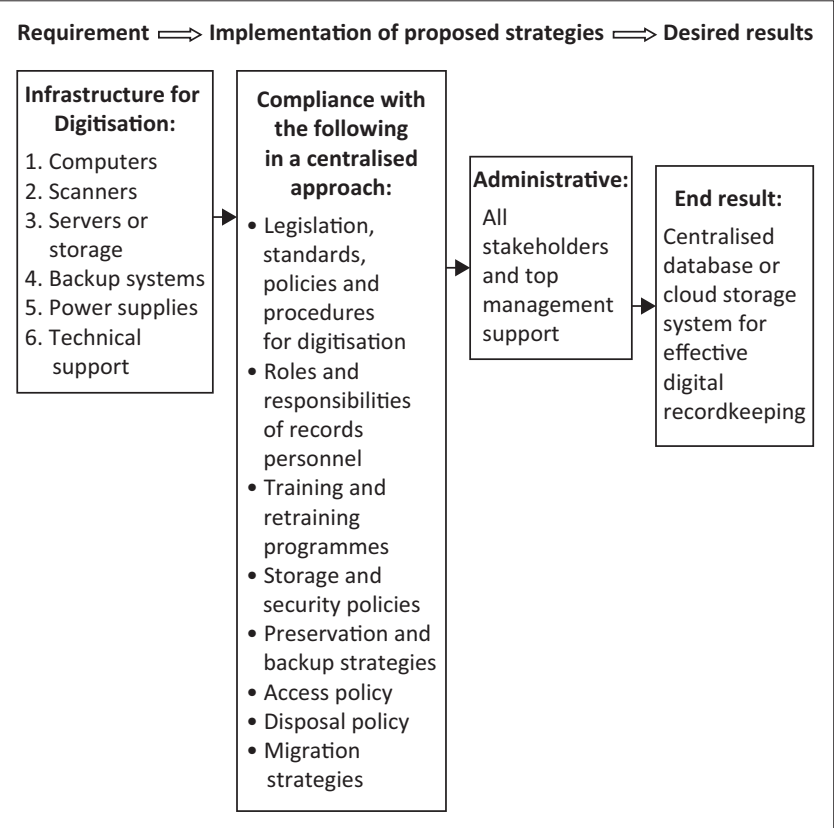

FIGURE 1: Centralised model to strengthen digitisation of records and archives. efficiency, reliability and flexibility of organisational records. In their study at the University of KwaZulu-Natal, Chinyemba and Ngulube (2005) also revealed that the problems of records management were because of the fact that the university had no central repository of expertise for records management.

The centralised model recommended in this study helps to integrate business procedures with records system procedures in order to strengthen control of all information coming into and going out of the universities. The infrastructure required for a smooth digitisation process includes computers, scanners, servers or storage, backup systems, constant power supplies and technical support of personnel with the requisite skills. Accordingly, the proposed centralised framework in Figure 1 is underpinned by the infrastructure, compliance with legislative and policy issues, administrative, which include all stakeholders and top management support and the end result which is keeping the records in a centralised database or cloud-based records storage system. Effective legislation and policies are required for the systematic, effective and efficient management of records and archives at state universities (Tsvuura \& Ngulube 2020:23). This is in view that Zimbabwe as a developing country still faces inevitable hurdles and problems, such as lack of appropriate legislation, policies and procedures, required to effectively manage digitised records and archives.

A central database system or a cloud-based records management system, which is controlled centrally, is required for storage of digitised records and archives, and not on individual computer drives. The centrality of the model is that a central database system or a cloud storage facility must be in place where all the records will be stored in one server and not in different computer drives that often make the records decentralised, having a great risk of being lost. This requires a change in organisational recordkeeping culture, as well as staff working habit, attitudes and responsibilities. This model also requires employees to understand legislation, policy, procedures and organisational structure in order to minimise resistance, which can be a major hurdle to the successful implementation of the digitisation programme. Munkvold and Zigurs (2007) argued that a lack of understanding of organisational circumstances can result in misunderstandings and make digitisation hard to utilise in an efficient way.

Another critical measure in this model is the ability to track the registration, where each record provides evidence of its existence and perpetuates its attestation to its integrity and its relationship with other records. The model allows the universities to reduce storage space as the records will be stored in a cloud or centralised database storage system. In this way, the universities can enjoy the benefits of digitisation of records and archives. Tsvuura and Ngulube (2020:21) alluded that such a technological process creates the possibility to improve service delivery in the universities. 


\section{Conclusion}

The study findings established that there was no central model to manage digitised records and archives at the selected state universities. This study recommended a centralised model for managing digital records in state universities in Zimbabwe. This would help in tracking the records, starting from the type of record to be created or received, and by whom, how the record is to be classified, audited as well as disposed of, including its level of confidentiality as it moves through the trenches of the business transactions.

\section{Acknowledgements}

The authors thank the two anonymous reviewers for their time and very helpful comments on earlier versions of this work, and the two independent coders who helped in resolving the coding difference between the researchers.

\section{Competing interests}

The authors declare that they have no financial or personal relationships that may have inappropriately influenced them in writing this article.

\section{Author's contributions}

P.N. contributed $40 \%$ of the inputs article and G.T. accounted for the $60 \%$ as described above.

\section{Ethical considerations}

The low-risk application was reviewed by the College of Graduate Studies Ethics Review Committee on 09 March 2021 in compliance with the University of South Africa (UNISA) Policy on Research Ethics and the Standard Operating Procedure on Research Ethics Risk Assessment. This study is based on questionnaires and interviews with adults.

\section{Funding information}

This research received no specific grant from any funding agency in the public, commercial or not-for-profit sectors.

\section{Data availability}

Data are available from the corresponding author (P.N.) upon request.

\section{Disclaimer}

The views and opinions expressed in this article are those of the authors and do not necessarily reflect the official policy or position of any affiliated agency of the authors.

\section{References}

Abdulkadhim, H., Bahari, M., Bakri, A. \& Hashim, H., 2015, 'Exploring the common factors influencing electronic document management system (EDMS) implementation in government', ARPN Journal of Engineering and Applied Sciences 10(23), 17945-17952.

Alkhofani, W., Yusof, Z.M., Mohamed, H. \& Mukred, M., 2019, 'The significant factors for the implementation of digital records management initiatives in Yemen: A conceptual framework', International Journal of Technical Innovation in Modern Engineering and Science 5(3), 1066-1074.
Alzubi, K.N., Aldhmour, F.M. \& Ali, H.B., 2015, 'An investigation of factors influencing the adoption of electronic management based on the theory of reasoned action (TRA): A case study in the University of Technology', International Journal of Computer Applications 123(18), 1-9. https://doi.org/10.5120/ijca2015905296

Ambira, C.M., Kemoni, H.N. \& Ngulube, P., 2019, 'A framework for electronic records management in support of e-government in Kenya', Records Management Journal 29(3), 305-319. https://doi.org/10.1108/RMJ-03-2018-0006

Asima-Mokhtar, U. \& Yusof, Z.M., 2009, 'Electronic records management in the Malaysian public sector: The existence of policy', Records Management Journal 19(3), 231-244. https://doi.org/10.1108/09565690910999201

Asogwa, B.E., 2012, 'The challenges of managing electronic records in developing countries', Records Management Journal 22(3), 198-211. https://doi. org/10.1108/09565691211283156

Asogwa, B.E., 2013, 'The readiness of universities in managing electronic records', The Electronic Library 31(6), 792-807. https://doi.org/10.1108/EL-04-2012-0037

Asproth, V., 2005, 'Information technology challenges for long-term preservation of electronic records', International Journal of Public Information Systems 1, 27-37.

Balogun, T. \& Adjei, E., 2019, 'Challenges of the national archives of Nigeria', Information Development 35(4), 612-623. https://doi.org/10.1177/0266666918778099

Chaterera, F., 2012, 'Towards harnessing e-government adoption in Zimbabwe', Mousaion: South African Journal of Information Studies 30(2), 78-93.

Chinyemba, A. \& Ngulube, P., 2005, 'Managing records at higher education institutions: A case study of the University of KwaZulu-Natal, Pietermaritzburg Campus', South African Journal of Information Management 7(1), a250. https://doi.org/10.4102/ sajim.v7i1.250

Creswell, J.W., 2014, Research design: Qualitative, quantitative and mixed methods approaches, 4th edn., Sage, Thousand Oaks, CA.

Cucciniello, M., 2015, 'Understanding key factors affecting electronic medical records implementation: A sociotechnical approach', BMC Health Services Research 15(1), implementation: A sociotechnical approach', BMC

Cumming, K. \& Findlay, C., 2010, 'Digital recordkeeping: Are we at tipping point?', Records Management Journal 20(3), 265-278. https://doi. Records Management Journo

Dube, T., 2011, 'Archival legislation and the challenge of managing archives in Zimbabwe', ESARBICA Journal 30, 279-290.

Duranti, L., 2009, 'From digital diplomatics to digital records forensics', Archivaria 68 , 39-66.

Duranti, L., 2010, 'Concepts and Principles for the management of electronic records, or records management theory is archival diplomatics', Records Management Journal 20(1), 78-95.

Duranti, L. \& Jansen, A., 2016, Authenticity of digital records: An archival diplomatics framework for digital forensics, viewed 05 January 2018, from http://www. researchgate.net/publication/290042000_Authenticity_of_digital_records_An archival_diplomatics_framework_for_digital_forensics.

Floridi, L., 2014, The fourth revolution: How the Infosphere is reshaping human reality, Oxford University Press, Oxford.

Fuin-Hoon Nar, F., Lee-Shang Lau, J. \& Kuang, J., 2001, 'Critical factors for the successful implementation of enterprise systems', Business Process Management Journal 7(3), 285-296. https://doi.org/10.1108/14637150110392782

Goodhue, D.L. \& Thompson, R.L., 1995, 'Task-technology fit and individual performance', JSTOR 19(2), 213-236. https://doi.org/10.2307/249689

Haradhan, M., 2018, 'Qualitative research methodology in social sciences and related subjects', Journal of Economic Development, Environment and People 7(1), 23-48. https://doi.org/10.26458/jedep.v7i1.571

Hasanain, R.A., Vallmuur, K. \& Clark, M., 2015, 'Electronic medical records systems in Saudi Arabia: Knowlegde and preferences of healthcare professionals', Journal of Health Informatics in Developing Countries 9(1), 23-31.

Hofman, D., Duranti, L. \& How, E., 2017, 'Trust in the balance: Data protection laws as tools for privacy and security in the cloud', Algorithms 10(2), 47. https://doi. org/10.3390/a10020047

Huni, P. \& Dewah, P., 2019, 'Admissibility of digital records as evidence in Bulawayo High Court in Zimbabwe', Journal of the South African Society of Archivists 52, 133-148.

InterPARES Project, 2014, International research on permanent authentic records in electronic systems, viewed 16 January 2020, from http://www.interpares.org.

Kamatula, G.A., 2010, 'E-government and e-records: Challenges and prospects for African records managers and archivists', Eastern and Southern Africa Regional Branch of the International Council on Archives (ESARBICA) Journal 29(2010), 147-164. https://doi.org/10.4314/esarjo.v29i1.64294

Katuu, S., 2000, 'Managing electronic records: An overview', Information and Development 16(1), 34-36. https://doi.org/10.1177/0266666004240134

Lincoln, Y.S. \& Guba, E.G., 1985, Naturalistic inquiry, Sage, Beverly Hills, CA.

Lipchak, A. \& McDonald, J., 2003, Electronic government and electronic records: E-records readiness and capacity building, viewed 03 December 2015, from http://www.irmt.org/documents/researc../e.pdf.

Majid, U., 2018, 'Research fundamentals: Study, design, population and sample size', URNCST Journal 2(1), 1-7. https://doi.org/10.26685/urncst.16

Malhotra, A. \& Majchrazk, A., 2005, 'Virtual Workspace Technologies', MIT Sloan Management Review 46(2), 11-14.

McDonald, J., 2002, 'Government on-line and electronic records', in B.W. Dearstyne (ed.), Effective approaches for managing electronic records and archives, pp. 73-88, Scarecrow Press, Lanham, MD. 
Miles, M.B., Huberman, A.M. \& Saldana, J., 2013, Qualitative data analysis: A methods sourcebook, Sage, Thousand Oaks, CA.

Mukred, M. \& Yusof, Z.M., 2018, 'The performance of educational institutions through the electronic records management systems: Factors influencing electronic records management system adoption', International Journal of Information Technology Project Manage 9(3), 35-51. https://doi.org/10.4018/IIITPM.2018070103

Mukred, M., Yusof, Z.M., Alotabi, F.M., Mokhtar, U. \& Fauzi, F., 2019, 'The key factors in adopting an electronic records management system in the educational sector: A UTAUT-based framework', IEEE Access 7, 35963-35980. https://doi.org/10.1109/ ACCESS.2019.2904617

Munetsi, B., 2011, Digitisation of archival collections in Africa communications: Issues, strategies and challenges, Library Philosophy and Practice e-Journal, Paper 651, viewed 16 January 2020, from http://digitalcommons.unl.edu/libphilprac.

Munkvold, B. \& Zigurs, I., 2007, 'Process and technology challenges in swift-starting virtual teams', Information and Management 44(3), 287-299. https://doi. org/10.1016/j.im.2007.01.002

Mutsagondo, S., 2017, 'Electronic records management in the Midlands Province of Zimbabwe', MIS thesis, University of South Africa, Pretoria.

Mutsagondo, S., 2021, 'The role of the national archives of Zimbabwe in fostering professional management of email in Zimbabwe's central government', International Journal of Management Research and Emerging Sciences 11(1), 94-103.

Mutsagondo, S. \& Chaterera, F., 2016, 'Mirroring the national archives of Zimbabwe Act in the context of electronic records', Information Development 32(3), 254-259. https://doi.org/10.1177/0266666914538272

Mutsagondo, S. \& Ngulube, P., 2018, 'Skills impact assessment of personnel managing electronic records in Zimbabwe's public service', Mousaion 36(2), 1-19. https:// doi.org/10.25159/2663-659X/3283

Mutsagondo, S. \& Tsvuura, G., 2017, 'Dilemma in disposing electronic mail records in public departments: The Zimbabwean scenario', Paradigms: A Research Journal of Commerce, Economics and Social Sciences 11(2), 190-195.

Nasieku, A.P., 2012, 'A framework for managing electronic records. The case of Moi University, Kenya', paper presented as SCECSAL XXth Conference by Kenya Library Association 4th - 8th June, Kenya Library Association, Nairobi.

Ngulube, P., 2012, 'Ghosts in our machines: Preserving public digital information for the sustenance of e-government in sub-Saharan Africa', Mousaion 30(2), 128-136.

Nguyen, L., Bellucci, E. \& Nguyen, L.T., 2014, 'Electronic health records implementation: An evaluation of information system impact and contingency factors', International Journal of Medical Informatics 83(11), 779-796. https://doi.org/10.1016/j. ijmedinf.2014.06.011
Nguyen, L.T., Swatman, P., Fraunhlz, B. \& Salzman, S., 2009, 'EDRMS implementation in the Australian public sector', Australisian Conference on Information System (ACIS) Proceedings 16, 915-928, viewed 17 July 2020, from http://aisel.aisnet. org/acis2009/16.

Orlikowski, W., 2000, 'Using technology and constituting structures: A practice lens for studying technology in organisations', Organization Science 11(4), 404-428. https://doi.org/10.1287/orsc.11.4.404.14600

Ouma, E., 2012, 'Positioning the National Archives of Zimbabwe for the knowledge economy', in P. Ngulube (ed.), National Archives 75@30: 75 years of archiving excellence at the National, pp. 28-36, Archives of Zimbabwe, Harare.

Saldana, J., 2015, The coding manual for qualitative researchers, Sage, Thousand Oaks, CA.

Shatat, A.S., 2015, 'Critical success factors in enterprise resource planning system implementation: An explaratory study in Oman', Electronic Journal of Information Systems Evaluation 18(1), 36-45.

Sigauke, D.T., Nengomasha, C.T. \& Chabikwa, S., 2016, 'Management of e-mail as electronic records in state universities in Zimbabwe: Findings and implications for the national archives of Zimbabwe', ESARBICA Journal 35, 14-29.

Smit, F., Glaudemans, A. \& Jonker, R., 2017, Archives in liquid times, GTV Drukwerk, Stichting Archietpublicaties, Amsterdam.

Strauss, A. \& Corbin, J., 1990, Basics of qualitative research: Grounded theory procedures and techniques, Sage, Newbury Park, CA.

Thibodeau, K., 2013, 'Wrestling with shape-shifters: Perspectives on preserving memory in the digital age', in The memory of the world in the digital age: Digitization and preservation, pp. 15-23, UNESCO, Vancouver, BC, viewed 15 December 2015, from http://www.unesco.org/webworld/download/mow/mow vancouver_proceedings_en.pdf.

Tsvuura, G., 2020, 'Digitisation of records and archives at two selected state universities in Zimbabwe', PhD thesis, Zimbabwe Open University, Harare.

Tsvuura, G., Mbawuya, D.K. \& Ngulube, P., 2021, 'New cloth in an old overcoat: A content analysis of the National Archives of Zimbabwe Act [Chapter 25;06] in the management of electronic records in Zimbabwe', International Journal of Research and Innovation in Social Science 5(3), 120-128.

Tsvuura, G. \& Mutsagondo, S., 2015, 'The role of tertiary education institutions in the development of records and archives management discipline in Zimbabwe', development of records and archives management disciplin
International Journal for English and Education 4(2), 458-470.

Tsvuura, G. \& Ngulube, P., 2020, 'Digitisation of records and archives at two selected state universities in Zimbabwe', Journal of the Society of South African Archivists 53(2020), 20-34. https://doi.org/10.4314/jsasa.v53i1.2

Victorian Auditor-General's Office, 2016, Records management checklist, viewed 14 May 2021, from https://www.audit.vic.gov.au/records-management-checklist.

Yin, R.K., 2014, Case study research: Design and methods, 5th edn., Sage, Thousand Oaks, CA. 